\title{
Asymptomatic lunotriquetral coalition: an incidental radiographic finding
}

\author{
Selahattin Ozyurek, ${ }^{1}$ Ferhat Guler, ${ }^{2}$ Kerem Canbora, ${ }^{3}$ Ozkan Kose ${ }^{2}$
}

${ }^{1}$ Department of Orthopaedics and Traumatology, Aksaz Military Hospital, Mugla, Turkey

${ }^{2}$ Department of Orthopaedics and Traumatology, Antalya

Education and Research Hospital, Antalya, Turkey ${ }^{3}$ Department of Orthopaedics and Traumatology, Haydarpasa Numune Education and Research Hospital, Istanbul, Turkey

Correspondence to Dr Selahattin Ozyurek, fsozyurek@yahoo.com

\begin{tabular}{l}
\hline To cite: Ozyurek S, Guler F, \\
Canbora K, et al. BMJ Case \\
Rep Published online: \\
[please include Day Month \\
Year] doi:10.1136/bcr-2013- \\
009429 \\
\hline
\end{tabular}

\section{DESCRIPTION}

A 40-year-old woman presented to our orthopaedic clinic with left-sided wrist pain after falling. On physical examination, there was no limitation in range of motion of the wrist; however, flexion and extension were minimally painful. There was no swelling or tenderness in the wrist. Other findings were normal. Plain anteroposterior radiograph of left wrist showed a left-sided osseous fusion of the lunate and triquetrum with a distal notch according to Minaar's classification type II (figure 1). MRI also revealed the lunotriquetral coalition Minaar type II confirming the stable proximal fusion of the bones with a distal notch of the left wrist and no bone oedema (figure 2). Analgesics and bandage to the left wrist was given. The patient became asymptomatic and returned to her normal activities within 5 days.

Carpal coalitions are rare, asymptomatic entities that most often present as incidental findings. The most common coalition is of the luno-triquetral type followed by the capito-hamate coalition. It is more common in women 2:1 and African-Americans. While osseous coalitions of the lunate and the triquetrium are known to be asymptomatic, fibrocartilage lunate-triquetral coalitions can present as an uncommon cause for ulnar-sided wrist pain. ${ }^{12}$

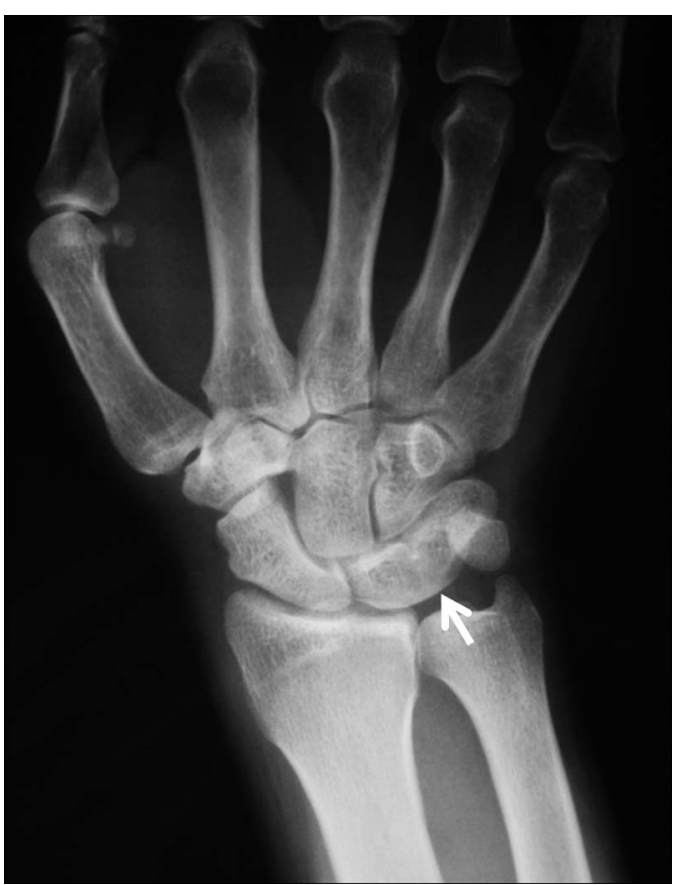

Figure 1 Anteroposterior radiograph of the left asymptomatic wrist showing a lunotriquetral coalition Minaar type I.

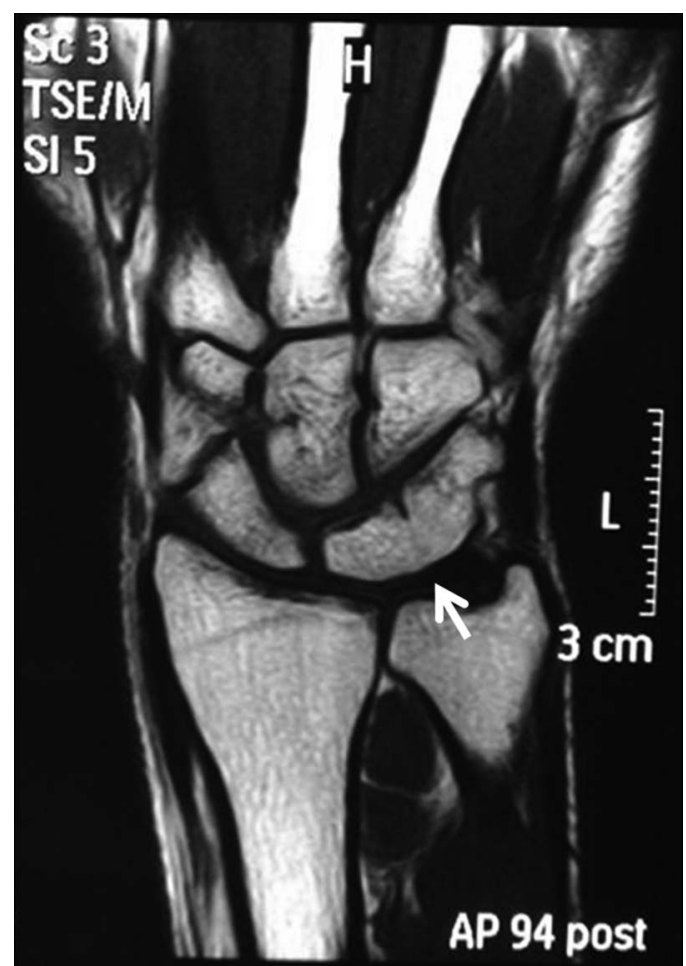

Figure 2 MRI shows the lunotriquetral coalition Minaar type II confirming the stable proximal fusion of the bones with a distal notch of the left wrist.

Minaar classified this anatomical variation in four types. Type I represents an incomplete fusion similar to a pseudoarthrosis (fibrocartilage coalition), type II an incomplete osseous fusion with distal notch, type III a complete osseous fusion (os lunatotriquetrium) and type 4 a complete osseous fusion associated with other carpal anomalies. ${ }^{3}$

\section{Learning points}

- Lunotriquetral coalition is the most common type of congenital carpal anomaly and represents congenital fusion of the lunate and triquetral bones of the carpus.

- It is most often diagnosed as an incidental finding in asymptomatic patients.

- Lunotriquetral coalition can be associated with other synostoses or malformations as a part of syndromic manifestations.
Contributors All authors have contributed equally in preparing the manuscript research, review, writing and all of them have approved the final draft of the article. 
Competing interests None.

Patient consent Obtained.

Provenance and peer review Not commissioned; externally peer reviewed.
2 Lotter $\mathrm{O}$, Stahl S, Luz O, et al. Bilateral paradoxically symptomatic luno-triquetral coalition: a case report. Eplasty 2010;10:e47.

3 Suresh SS. Unusual coalition of the carpal bones with simian crease: a case report. Acta Orthop Traumatol Turc 2011;45:379-81.

\section{REFERENCES}

1 Pfirrmann CW, Zanetti M. Variants, pitfalls and asymptomatic findings in wrist and hand imaging. Eur J Radiol 2005;56:286-95.

Copyright 2013 BMJ Publishing Group. All rights reserved. For permission to reuse any of this content visit http://group.bmj.com/group/rights-licensing/permissions.

BMJ Case Report Fellows may re-use this article for personal use and teaching without any further permission.

Become a Fellow of BMJ Case Reports today and you can:

- Submit as many cases as you like

- Enjoy fast sympathetic peer review and rapid publication of accepted articles

- Access all the published articles

- Re-use any of the published material for personal use and teaching without further permission

For information on Institutional Fellowships contact consortiasales@bmjgroup.com

Visit casereports.bmj.com for more articles like this and to become a Fellow 